\title{
Landscape restoration due to Xylella fastidiosa invasion in Italy: Assessing the hypothetical public's preferences
}

\author{
Michel Frem ${ }^{1,4}$, Fabio Gaetano Santeramo², Emilia Lamonaca ${ }^{2}$, \\ Maroun El Moujabber ${ }^{3}$, Elia Choueiri ${ }^{4}$, Pierfederico La Notte ${ }^{5}$, \\ Franco Nigro', Francesco Bozzo ${ }^{6}$, Vincenzo Fucilli ${ }^{6}$
}

\begin{abstract}
I Università degli Studi di Bari-Aldo Moro, Dipartimento di Scienze del Suolo, della Pianta e degli Alimenti (Di.S.S.P.A.), Via Amendola 165/A, 70126, Bari, Italy 2 Università degli Studi di Foggia, Dipartimento di Scienze Agrarie, Alimenti, Risorse Naturali e Ingegneria, Via Napoli 25, 71122, Foggia, Italy 3 CIHEAM Bari, Istituto Agronomico Mediterraneo, Via Ceglie 9, 70010, Valenzano, Bari, Italy 4 Lebanese Agricultural Research Institute, Department of Plant Protection, Tal Amara, P.O. Box 287, Zablé, Lebanon 5 Consiglio Nazionale delle Ricerche, Istituto per la Protezione Sostenibile delle Piante, Via Amendola 122/I, 70126, Bari, Italy 6 Università degli Studi di Bari - Aldo Moro, Dipartimento di Scienze Agro Ambientali e Territoriali (Di.S.A.A.T.), Via Amendola 165/A, 70126, Bari, Italy
\end{abstract}

Corresponding author: Michel Frem (mefrem@lari.gov.lb)

Academic editor: Shana McDermott | Received 20 April 2021 | Accepted 8 June 2021 | Published 2 July 2021

Citation: Frem M, Santeramo FG, Lamonaca E, El Moujabber M, Choueiri E, La Notte P, Nigro F, Bozzo F, Fucilli V (2021) Landscape restoration due to Xylella fastidiosa invasion in Italy: Assessing the hypothetical public's preferences. NeoBiota 66: 31-54. https://doi.org/10.3897/neobiota.66.67648

\begin{abstract}
Since 2013, the olive landscapes have gradually degenerated due to the spread and establishment of Xylella fastidiosa subsp. pauca (hereafter $X f$ ) in Apulia, southern Italy. From 2013 to 2019, a total of approximately 54,000 hectares of olive orchards in the south of this region have been seriously damaged, and their restoration will progressively regenerate the economic, social, cultural and environmental nonmarket benefits. Since there is a willingness to restore the affected landscape in the best interest of the local citizens, this research aims to predict their preference heterogeneity and willingness to pay (WTP) to improve this landscape and continue research and experimentation in relation to Olive Quick Decline Syndrome Disease by the bacterium. For this purpose, a choice experiment method is used. The social field survey includes a representative sample of 683 respondents in three major cities (Foggia, Bari and Lecce) of Apulia region. The results reveal that for the local citizens interviewed, the most appreciated olive landscape services are cultural heritage and aesthetic values. In addition, the findings revealed citizens' positive appreciation of improving the damaged olive landscape, while respondents are not willing to pay a premium for research.
\end{abstract}

Copyright Michel Frem et al. This is an open access article distributed under the terms of the Creative Commons Attribution License (CC BY 4.0), which permits unrestricted use, distribution, and reproduction in any medium, provided the original author and source are credited. 
The results show that the average value that Apulians are willing to pay for landscape restoration is about 5.7 million of $€$ per year. Further, this research has implications for land use planners in the study area, which faces issues of harmful pathogen management and land revival.

\section{Keywords}

alien species, biological invasion impact, choice experiment, economic costs, ecosystem services, environmental changes, social perception, willingness-to-pay

\section{Introduction}

Olive-growing is recognized as a multifunctional ecosystem in Italy. It shapes the landscape of the countryside with a particularly visual spatial representation (Lanfranchi and Giannetto 2012). Furthermore, this aesthetic value is not only the absolute nonmarket feature of this ecosystem, but provides considerable socio-cultural services (Severini 2006), economic effects (Viganò 2006), ecological benefits (Bernetti et al. 2006; Torquati et al. 2006), and conservation of the agro-biodiversity (Corrado et al. 2011; Fernández-Habas et al. 2018). However, since 2013, a part of this rural landscape has increasingly lost these attributes in the Salento Peninsula of Apulia in southern Italy. Consequently, a total of approximately 22 million plants have been affected and approximately 6.5 million olive trees died (Beck et al. 2019), causing real damage to the landscape and identity of the study area.

The loss is due to Olive Quick Decline Syndrome Disease (OQDS, previously known as "CoDiRO", recently named "De Donno") (Saponari et al. 2013, 2018) caused by Xylella fastidiosa subsp. pauca (hereafter $X f$ ), a quarantine plant pathogen for the EU area, where stringent and specific regulations apply. So, Apulian olive trees of Lecce province were affected by $X f$ and characterized by leaf scorching, scattered desiccation of twigs and branches conferring thus a burned aspect and subsequent tree mortality (Saponari et al. 2013) as shown in Pictures 1, 2. The most severely and impressively affected olives are the centuries-old trees of the local highly susceptible cultivars Cellina di Nardò and Ogliarola salentina which marked by (OQDS) from incipient signs of infection to plant death. Monumental trees with a skeletal appearance, severely pruned to promote new vegetation, have shown dramatic decline and severe symptoms of desiccation where the few shoots produced are already dead. In the field, remarkable differential response to natural infection by $X f$ (Giampetruzzi et al. 2017) was revealed in adjacent rows of olive trees of cultivars Leccino and Ogliarola salentina and comparative analysis of the transcriptome of these varieties was carried out to investigate the reasons for this differential behavior (Giampetruzzi et al. 2016). Moreover, in experimental fields and controlled conditions for the evaluation of resistance/susceptibility of the varieties/species, through mechanical inoculation with bacterial cultures, strain "De Donno", does not infect grapevines and citrus whereas it multiplies readily in oleander, olive seedlings and rooted cuttings of cv. Cellina di Nardò and to a much lesser extent in other olive cultivars like Coratina, Frantoio, Leccino (European Food 


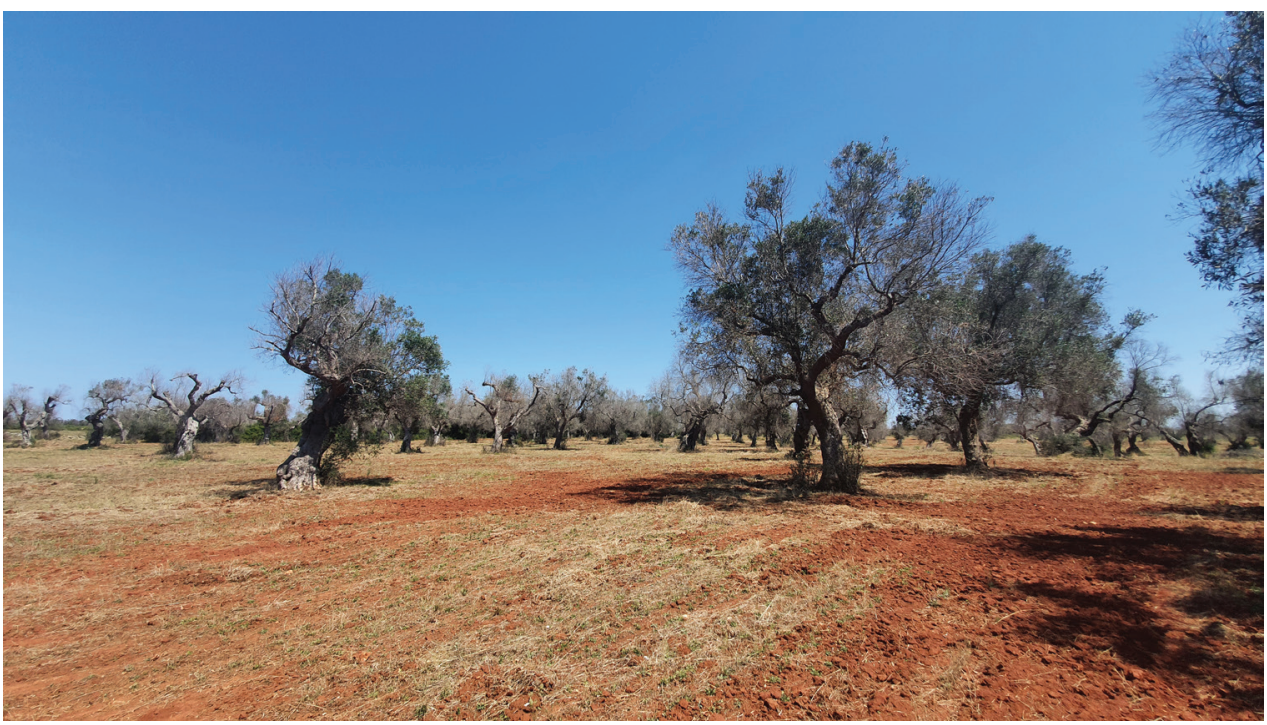

Picture I. Olive leaf scorching due to Xylella fastidiosa invasion in Apulia region. Source: Infoxylella.

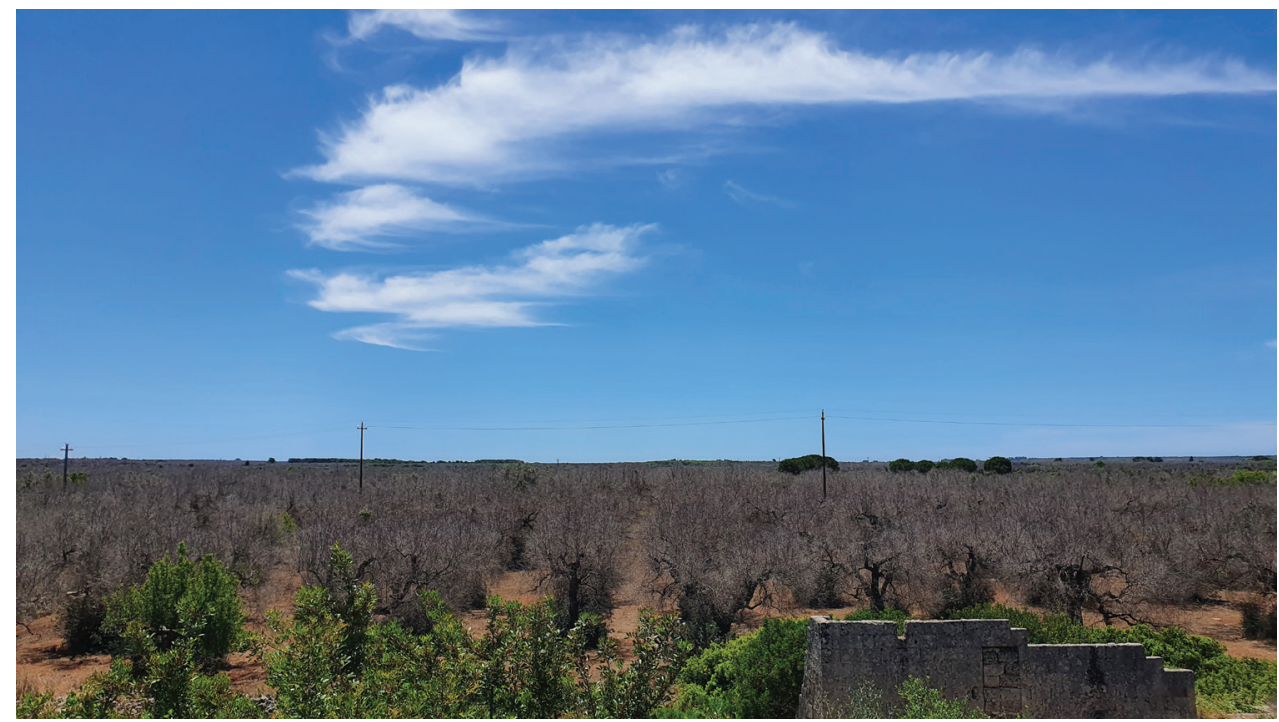

Picture 2. Olive trees mortality caused by Xylella fastidiosa in Apulia region. Source: Infoxylella.

Safety Authority 2015; Saponari 2016). However, one of the best solutions was the search for resistant varieties which are a highly desirable approach with the aim of the possible reconstitution of the Salentinian olive industry based on a set of cultivars that can replace for the largely predominant and highly susceptible ones. Leccino and FS17 have already been identified and a patch-graft with these resistant varieties on old infected olive trees was piloted, considering this cultural practice as an encouraging starting point in the research for resistant material. 
This bacterium (Sequence Type 53) originating on coffee plants in Costa Rica is driven by an insect-vector, Philaenus spumarius, which is widely distributed in Apulia region (Bosco 2014; European Food Safety Authority 2015; Martelli et al. 2015). Further, Frem et al. (2020) predicted that this bacterium may invade new European and Mediterranean countries. However, the bacterium was also detected in Neophilaenus campestris and Euscelis lineolatus indicating the potential vectoring roles of these insects for the spread of the bacterium in Apulian region (Elbeaino et al. 2014) while the spittlebug $P$. spumarius was the most abundant species found in orchards on both weeds and olive trees in Italy (Cornara et al. 2017). To better understand the role of the host plant on the ecology of the infections, numerous plant species have been shown to be colonized by Xfin southern Apulia, including almond, oleander, cherry and other species (Saponari et al. 2013, 2014). This may confirm the impacts of host plant species on the efficiency of transmission of $X f$ by $P$. spumarius and therefore the ability of the bacterium to spread rapidly and trigger an outbreak. $X f$ colonizes the xylem network of the trees (Wells et al. 1987).

As a consequence, by destroying the rural landscape in the study area, $X f$ is gradually inducing changes in olive trees landscape which provides a set of economically valuable goods and provisioning services such as food diet (olive and olive oil), regulating services that affect climate, biodiversity, sustainable agriculture and cultural services that provide recreational, aesthetic, and educational and research features. Thereby, these benefits contribute towards daily life and human well-being in terms of health, security, good life and social relations. Ultimately, linking these attributes to human wellbeing constitutes an integral part of the economic analysis that is applied when decisions are necessary for the concerned stakeholders to manage a biological invasion process (Emerton and Howard 2008). In this framework, the Figure 1 highlights the links between $X f$ invasion, olive landscape services and public's well-being. Changes in ecosystem services and human well-being, give rise to assess the public's preferences about landscape recovery.

Furthermore, the provision of ecosystem services is not perceived or observed similarly by all social groups (Sardaro et al. 2016a). Therefore, assessing their preferences about ecosystem recovery such as olive landscape restoration constitutes an integral part of the economic analysis of invasive species that is applied when policy decisions should be taken to manage biotic invasions (Emerton and Howard 2008). Moreover, Apulian residents as taxpayers would pay additional costs for landscape recovery and rehabilitation. Meanwhile, residents' preferences or opinions must be taken into consideration in the decision-making process (Haltia 2015) in order to comprehensively assess landscape (Tagliafierro et al. 2013). Without this consideration, the prevention of wasteful and imprudent resource allocation cannot be guaranteed. Given this, this research aims to provide an assessment of local citizens' preferences for different olive landscapes changes and for pursuit of research associated to $X f$. Also, the study provides their WTP for the improvement of the damaged olive landscape in Apulia within an economic analysis of biotic invasive framework. Burgess et al. (2012) points out that citizens' preferences in relation to a non-excludable and non-rivalrous environmental 


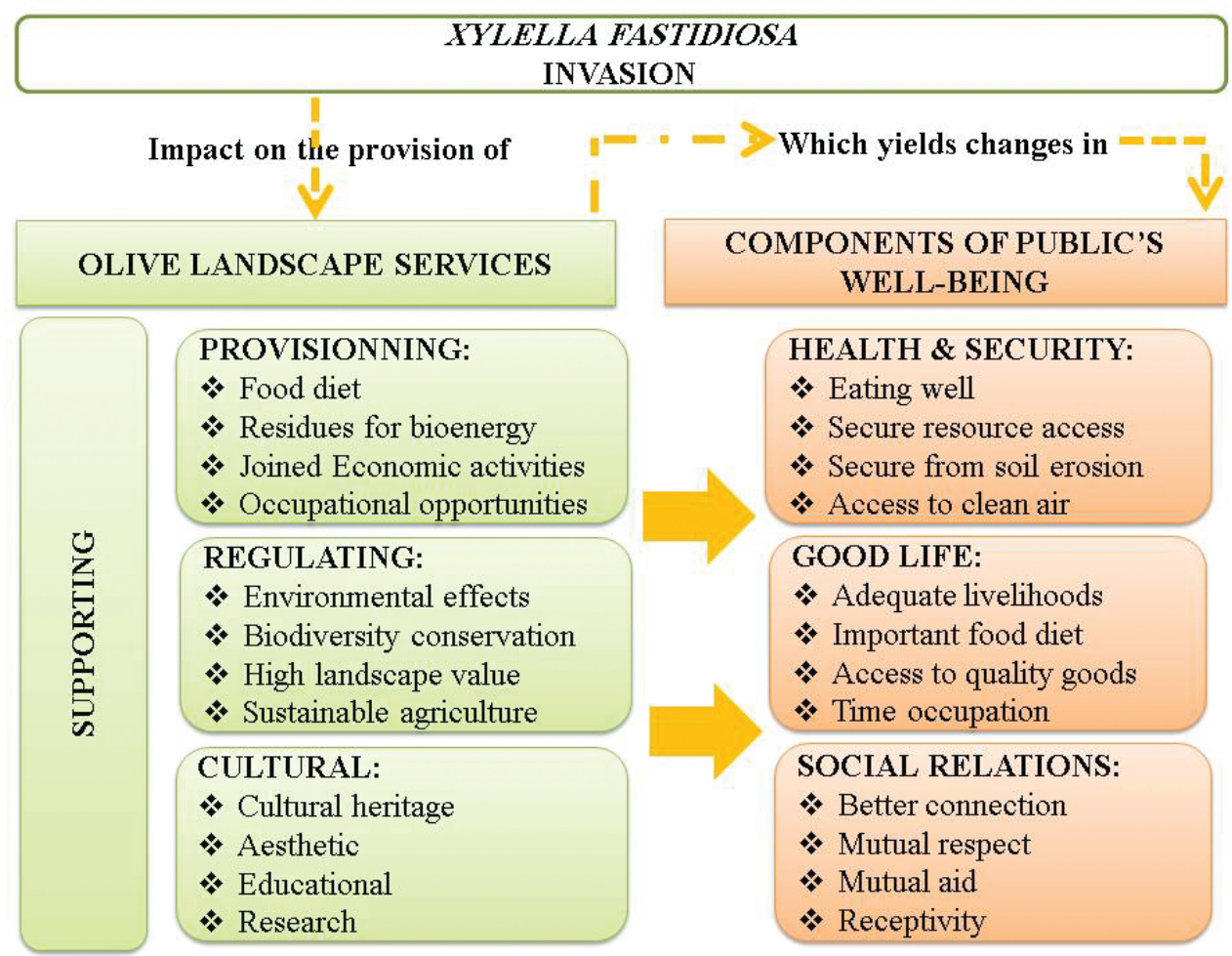

Figure I. Overview of the impact of Xylella fastidiosa on olive landscape services based on the general illustration of Emerton and Howard 2008.

non-market public good, are commonly examined by economists through non-market evaluation techniques (Figure 2) which are classified in two groups: revealed preference methods (i.e. market price, cost-based, hedonic pricing and travel cost) and stated preference methods (i.e. contingent valuation method, CVM and choice experiment, CE). The first group is limited to market goods and services, but based on observed user behavior. The second group can be applied to all goods and services to capture all use and non-use values, but based on hypothetical situations of users and non-users (Plan Bleu 2016). Among these techniques, CE is preferred for rural landscape evaluation (Scarpa and Cicia 2000; Scarpa et al. 2007), and is used for the purpose of this study for the following reasons: (i) it is suitable for evaluating multi-attribute ecological goods (Arriaza-Balmón et al. 2006), (ii) it minimizes strategic bias across a set of choices (Bennett and Blamey 2001; Hanley et al. 2001), (iii) it captures total economic value (use and non-use values) of the ecosystem, and (iv) it allows consideration of public preferences in the context of environmental goods such as olive landscapes (Sardaro et al. 2016b). Unlike CE, where the choice set is composed of at least three options (status quo and two hypothetical alternatives), CVM is based on only two possibilities (status quo and one hypothetical alternative). 


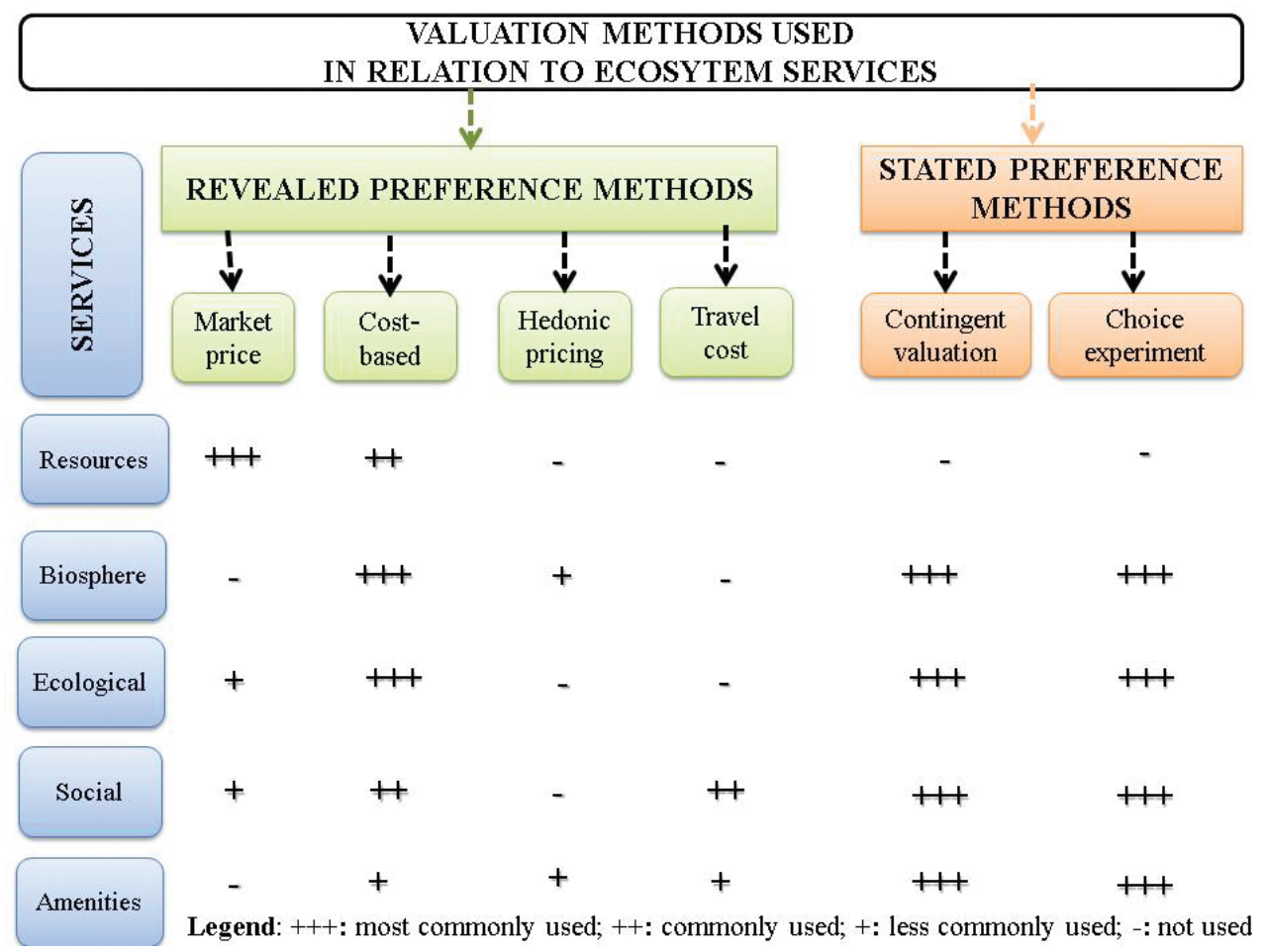

Figure 2. Summary of various techniques used to assess the economic, social and ecological economic impacts of invasive species. The diagram assembles two categories of methods (revealed preferences and stated preferences) where Choice Experiment belonging to the second category was considered in our study.

There have been several studies of valuation of environmental services and damages in the past decades. These include the valuation of a damaged ecological public good through CVM as a useful approach in public policy formulation (Portney 1994), environmental valuation through CE (Hanley et al. 2001; Scarpa et al. 2007; Campbell and Hynes 2011; Hasund et al. 2011), assessment of environmental damage in monetary terms through the WTP (Johansson 1990), valuation approaches for natural ecological functions (de Groot et al. 2002), the elicitation of factors affecting citizens' behavior towards the prevention of environmental damage (Torgler and Garcia-Valiňas 2007), the estimation of WTP for rural landscape changes (Campbell 2007), individuals' preferences for agri-environmental services (Garrod et al. 2014), and economic quantitative valuation of damages due to climate change (Auffhammer 2018). At the Italian level, one specific study has quantified the economic and landscape impact of $X f$ in the Salento area (Sardaro et al. 2015). However, this previous research is based on a direct income loss approach, rather than on stated preference methods. The addedvalue of the present research is twofold. First, the monetary values of non-market olive landscapes features, based on individuals' preferences, have never been yet assessed in the affected area. Second, the present paper enriches the scientific literature that uses 
CE to capture society's perception of research and experimentation activities, considered as an attribute in this study, to improve the representation of olive landscapes. The results have consequences for policy with respect to the recovery Plan (see below) for the damaged olive landscape and for pursuing ongoing research activities related to $X f$.

\section{Methods}

\section{Restoration Plan of the affected area}

The Italian Ministry of Agriculture (Ministero delle politiche agricole alimentari, forestali e del Turismo, hereafter Mipaaft) created an Action Plan (2020) to prevent dispersal of the bacterium and rebuild the landscape in infected areas. This plan defines all measures to be taken to counter the spread of $X f$ in line with the Implementing Decision (EU) 2015/789 and the Ministerial Decree of 13.02.2018 (and subsequent amendments) to relaunch the agricultural and agro-food sector of the areas affected by the bacterium in Apulia. The Plan includes a set of measures, in particular (i) restoration of the damaged landscape (i.e. removal of damaged plants, replanting and conversions via resistant olive cultivars, reconversion to other crops, preservation of monumental olive trees via grafting with resistant varieties, support for growers' incomes during the transition period to new plants, and financial support for plant nurseries to readjust their structure and facilitate transfer in disease-free areas), and (ii) pursuit of future $X f$ research and experimentation (i.e. genetic and epidemiological, vector control, innovation of large-scale monitoring techniques, improvement and development of diagnostic techniques and innovative tools for the surveillance and prevention in the free areas, and new treatments for the bacterium).

\section{Agricultural overview of the study area}

This study focused on the southern area of Apulia region, south-eastern Italy. Apulia has a total surface area of 1,954,052 hectares, distributed between its five provinces: Foggia (36\%), Barletta-Andria-Trani (8\%), Bari (20\%), Taranto (13\%), Brindisi (10\%) and Lecce (14\%). According to the National Statistics Institute (Istituto Nazionale di Statistica 2019), a variety of different crop types are present in Apulia. The agricultural area is mainly under cereals (29\%), followed by table and oil olives (27\%), temporary forage crops (17\%), and permanent grassland, pastures and meadows (15\%). In addition, Apulia accounts for $33.81 \%$ of Italy's olive-growing area and $33.22 \%$ of the country's olive production. The region's olive landscape is characteristic: $79 \%$ of the regional olive area is covered by trees over 50 years old (Ciervo 2016). In terms of trees, Apulia has 60 million plants on 382,600 ha (Istituto Nazionale di Statistica 2019), with around 3 million centenarian and millenarian plants, which capture particular cultural and aesthetic values (longevity from Roman times and the $17^{\text {th }}$ century) on 90,000 ha because of their impressive trunks and contorted shapes. Nevertheless, the 
Table I. Total area, areas and harvested production of table and oil olives in 2019.

\begin{tabular}{lcccc}
\hline \multicolumn{1}{c}{ Territory } & Total area $\mathbf{( 1 0 0 0}$ ha) & $\begin{array}{c}\text { Table and oil olives area } \\
(\mathbf{1 0 0 0} \text { ha })\end{array}$ & $\begin{array}{c}\text { Harvested production } \\
(\mathbf{1 0 0 0} \text { Tons })\end{array}$ & $\begin{array}{c}\text { Damaged area due to } \boldsymbol{X f} \\
(\mathbf{1 0 0 0} \text { ha)* }\end{array}$ \\
\hline Foggia & 701 & 55 & 81 & \\
Bari & 386 & 100 & 298 & 4 \\
Taranto & 247 & 35 & 69 & 10 \\
Brindisi & 186 & 64 & 12 & 40 \\
Lecce & 280 & 97 & 155 & 54 \\
Barletta-Andria-Trani & 154 & 33 & 95 & 54 \\
Total (Apulia region) & 1954 & 383 & 818 & 2461 \\
Total (Italy) & 30134 & 1166 & 245 & 54 \\
\hline
\end{tabular}

Source: Own elaboration based on data by www.istat.it. Extraction date: 19/04/2020. * Italia Olivicola 2019.

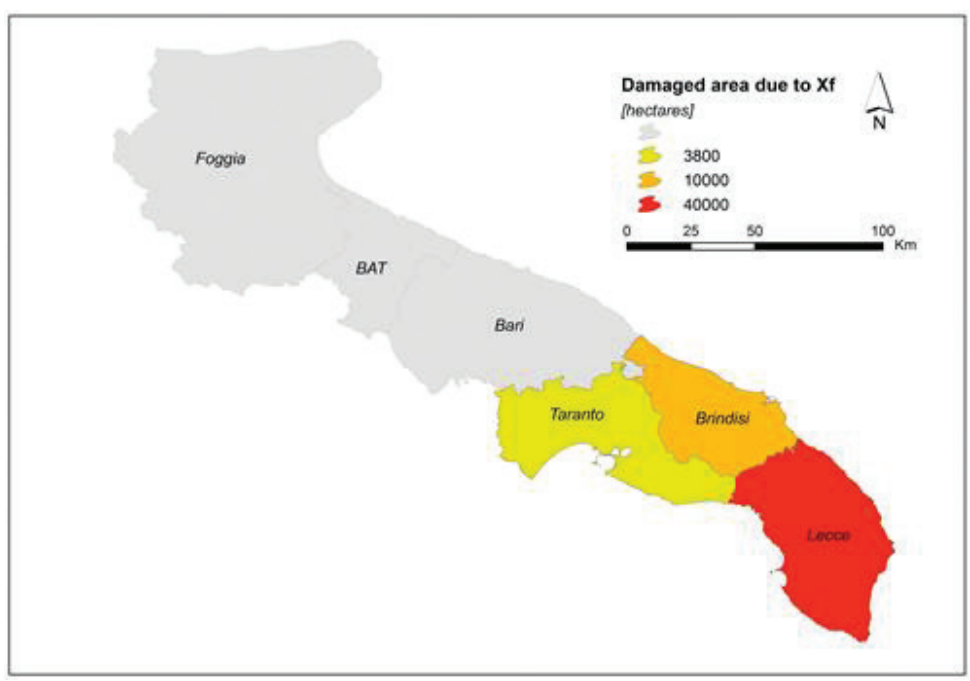

Figure 3. Distribution of the area (in ha) damaged by Xylella fastidiosa in Apulia region.

olive area that has been completely lost due to $X f$ represents $14.06 \%$ of Apulia's olivegrowing area and $4.61 \%$ of the national total (Table 1; Figure 3). Moreover, Apulia's lost production for three years (2016-2018) is estimated at 29,000 tons (equivalent to $€ 390$ million), representing $10 \%$ of Italian olive production (Italia Olivicola 2019).

\section{Respondents' choice preferences: conceptual framework}

In recent years, $\mathrm{CE}$ has been widely used to assess the non-market services of public goods (Dallimer et al. 2015; Zoderer et al. 2015; Sardaro et al. 2016b; Bottero et al. 2017; Tempesta and Vecchiato 2017; Cortignani et al. 2018; Novikova et al. 2019), and in particular to reveal respondents' (i.e. citizens, residents or tourists) preferences regarding the benefits of ecosystem services (Dachary-Bernard and Rivaud 2013). Based on utility theory (Lancaster 1966 as cited by Tempesta 2014), it has been assumed that respondents' utility for the olive landscape restoration is a function of 
changes in landscape, additional costs faced to implement landscape restoration, and other control factors (i.e. research and experimentation, communication plan). Conditional logit models to explain respondents' preferences for olive landscape restoration have been estimated. A baseline model (model 1) disentangles the preference for a change in landscape. Further models investigate whether respondents' preferences differ according to geographical location and options for land restoration: conditional logistic regressions include interaction variables between locations (i.e. respondent resident in Foggia and Lecce) and changes in landscape (model 2) and between options for land (i.e. traditional, intensive, disperse/sparse, productive crops, productive crops with bushes) and changes in landscape (model 3). This investigation derives respondents' willingness to pay (WTP) as the ratio between the estimated parameter for options of landscape restoration and the negative of the parameter estimated for additional costs: each ratio reflects the average contribution a respondent would pay for landscape restoration. The rest of this section explores how these points have been addressed in this research. The options for landscape restoration have been defined on the basis of information retrieved from: the restoration Plan (Mipaaft 2020) and a focus group discussion. Landscape restoration presents 5 levels of changes (illustrated by corresponding photographs), listed in Table 2 . As in previous studies on the quantification of Italian landscapes services (Tempesta and Vecchiato 2017), this research presents 5 levels of additional costs that citizens are willing to pay for landscape restoration $(0,15,30,60 \& 90 €$ per household/year for the next 10 years), illustrated by corresponding photographs. The experimental design includes also options for research and experimentation. The use of different photographs and/or pictograms was intended to help respondents in the choice process (Bateman et al. 2009; Zoderer et al. 2015). This visual information (Garrod et al. 2014) reflected the attributes under assessment to provide a stimulus to the respondent (De Ayala et al. 2012) and support the realism of the alternatives (Cherchi and Hensher 2015) in our CE experiment, in which respondents may easily select a choice set. The combination of the above attributes and their levels gave 120 possible scenarios $\left(2^{2} \times 5 \times 6\right)$. A fractional factorial design (Christie et al. 2004; Bush 2013) was decided using the code of package AlgDesign on $\mathrm{R}$, yielding 36 reasonable alternatives, which were divided into 3 blocks including 4 choices set each (see Table 3 as an example). Each choice set consisted of 4 columns. The first column described the areas of improvement (attribute) to guarantee the availability of the landscape for citizens today and for future generations. The next three

Table 2. Options for landscape restoration.

\begin{tabular}{ll}
\hline & \multicolumn{1}{c}{ Options for landscape restoration } \\
\hline - & Status quo; \\
- & Landscape with $X f$-resistant olive cultivars only in a traditional production system; \\
- & Landscape with $X$-resistant olive cultivars only in an intensive production system; \\
- & Landscape planted with mixed productive crops (i.e. vineyards, pomegranate, stone fruits); \\
- & Landscape planted with mixed productive crops and bushes. \\
\hline
\end{tabular}


Table 3. Example of a set choice.

\begin{tabular}{l|c|c|c}
\hline \multicolumn{1}{c|}{ Area of improvement } & Status quo & Alternative $A$ & Alternative $\boldsymbol{B}$ \\
\hline Landscape & Landscape not restored, like now & Traditional olive production system & $\begin{array}{c}\text { Landscape planted with mixed } \\
\text { productive crops and bushes }\end{array}$ \\
\cline { 2 - 5 } & & &
\end{tabular}

columns concerned the three different scenarios (known as alternatives) that could be chosen. These had no labels but were referred to as: "Status quo", "Alternative A" and "Alternative B". For each respondent, 4 choice sets were presented in order to select the alternative that maximizes satisfaction requirements

Furthermore, the experimental design was organized into 3 blocks of 4 choice sets each, based on: (i) the previous experience of the focus group experts (Hoyos 2010) in Italian landscape valuation and conservation, (ii) the pilot survey, (iii) the prevention of complexity, minimization of confusion and cognitive fatigue for respondents during the survey, and (iv) the common use of manageable number choice sets (i.e. not higher than 5 to 6) in the CE literature (Caussade et al. 2005; Campbell 2007; Kallas et al. 2007; Garrod et al. 2014; Weller et al. 2014; Cherchi and Hensher 2015). The elicitation of respondents' preferences was examined through a social-choice sample survey in which the structure of the questionnaire had three sections. Section 1 included attitudinal questions on respondents' general attitudes towards the olive landscape and its benefits, as well as their knowledge of the multi-functionality of the olive sector in Apulia. At the end of this section, interviewees were informed about the current Olive Quick Decline Syndrome epidemic caused by Xf, which gradually deprives the Apulian landscape of its historical, patrimonial and cultural element: its olive trees. Two representative photos from the European Commission website showing the severity of the disease and the map of the demarcated area affected were shown to respondents in case any of them were unaware of the problem. Section 2 concerned their preferences for improvement of the affected landscape. In this section, 4 choice sets were presented to the respondents in order to select the option 
that ensures the restoration of the affected landscapes in southern Apulia. In order to ascertain the certainty of their choices (Brouwer et al. 2010), participants were asked a question (how certain are you about your choice?) and indicated their answers on a scale from 1 (absolutely certain) to 4 (completely uncertain) at the end of each choice set. Furthermore, a set of statements was presented to respondents in order to best describe the way in which they made again their choices. Section 3 aimed to collect information about respondents' socio-economic characteristics (i.e. age, gender, residence, employment, sector of activity, membership of environmental associations, and annual income). An example of the questionnaire is enclosed in Suppl. material 1. A pilot survey was performed in order to define the time needed for face-to-face interviews and to guarantee that respondents fully understood the questionnaire. The final survey was carried out by qualified and trained agents in spring 2019, involving 683 respondents (general public) in three of Apulia's major cities (Foggia, Bari and Lecce), particularly in different contexts (i.e. in front of train and bus stations, public parks, local streets, etc.). Within each city, three blocks of the questionnaire were used. The Sections 1 and 3 of the questionnaire were kept constant, while Section 2 included four different sets of choices in each block. At least 60 people were interviewed randomly by block distributed between the sexes (at least 30 females and 30 males) and ages (at least 20 males and females for each of the following age ranges: 18 to 30, 30 to 50 and above 50 years old).

\section{Results}

\section{Basic descriptive statistics}

\section{Respondents' awareness and perception of Apulia's olive landscapes}

This section includes basic statistical results from the Section 1 of the questionnaire (Suppl. material 1), dealing with respondents' general attitudes towards the olive landscape and its benefits, and their knowledge of the multi-functionality of the olive sector in the studied area. Observations of the natural landscape and historical buildings in Apulia were the most popular activities. The majority of respondents (45.1\%) visited the Salento (damaged area) at some time within a year, while $33.1 \%$ of them live there, mainly in the Lecce area.

Although $17.1 \%$ of the participants in this social survey had not been there during the last 7 years, which means that they were not really aware of the incidence and severity levels of Olive Quick Decline Syndrome in the damaged area, almost all respondents (98.1\%) recognized the relative importance of the presence of the olive trees in Apulia's landscape. With regard to their level of agreement about olive landscape services, very few respondents $(0.6 \%)$ were convinced that this ecosystem does not provide benefits in Apulia, but $4.2 \%$ of them confirmed their ignorance about its ecosystem services. In general, the olive landscape obtained the highest agreement on its cultural heritage and 
aesthetic values (63.4\% in terms of historical olive germplasm, great enrichment of the Apulia region, attractive appearance and evergreen), followed in succession by its other services: food production $59.7 \%$ for food security, olives \& olive oils as common ingredients in the Italian diet, typical products), economic benefits (48.5\%, including olive sales, tourism, gastronomy, hospitality, direct sale), positive environmental effects (46.9\% related to biodiversity conservation, maintenance of native plants, animal life, sustainable agriculture, low use of chemical inputs, mitigation of the greenhouse effect, water management, prevention of soil erosion and run-off), social attributes $(32.1 \%$ for the maintenance of family farming and rural employment), and finally, research features $(27.7 \%$ as a field of research and experimentation).

\section{Respondents' socio-economic profiles}

According to latest data available on the website of Istituto Nazionale di Statistica (https://www.istat.it), our sample results (Table 4) are in a similar range to the main statistics of Apulia population (48.65\% males; average age 44.7; average family size 2.5; annual average household income in the south of Italy $€ 32,807)$. On average, respondents were middle-aged ( 41 years old), and equally divided between genders since $51 \%$ were male, but were widely differentiated with respect to family size (1 member: 4.7\%, 2 members: 16.8\%, 3 members: $31.6 \%$, 4 members: $38.9 \%$, more than 4 members: $7.9 \%)$. The average family size was approximately 3.3 . The majority $(70.1 \%)$

Table 4. The descriptive statistics of main variables for the entire sample.

\begin{tabular}{|c|c|c|c|c|c|c|}
\hline Variable & Categories & Median & Mean & Std. Dev. & Min & Max \\
\hline Age & Year & 39 & 41 & 16 & 18 & 86 \\
\hline Male & $\begin{array}{l}\text { Male } \\
\text { Female }\end{array}$ & 1 & 0.51 & 0.50 & 0 & 1 \\
\hline Resident in rural areas & $\begin{array}{l}\text { Rural area } \\
\text { Urban area }\end{array}$ & 0 & 0.08 & 0.27 & 0 & 1 \\
\hline Family members (Total number) & $\begin{array}{c}1 \\
2 \\
3 \\
4 \\
5 \& \text { more }\end{array}$ & 3 & 3.29 & 0.99 & 1 & 5 \\
\hline Family members (Under 18 years old) & Number & 0 & 0.40 & 0.70 & 0 & 4 \\
\hline Education level & \begin{tabular}{|c|} 
1: Not educated \\
2: Elementary school \\
3: Lower secondary school \\
4: High secondary school \\
5: University \\
\end{tabular} & 4 & 4.22 & 0.77 & 1 & 5 \\
\hline In work & $\begin{array}{c}\text { Yes } \\
\text { No }\end{array}$ & 1 & 0.67 & 0.47 & 0 & 1 \\
\hline Members of environmental associations & $\begin{array}{l}\text { Yes } \\
\text { No }\end{array}$ & 0 & 0.11 & 0.31 & 0 & 1 \\
\hline Olive grove owner & $\begin{array}{l}\text { Yes; } \\
\text { No }\end{array}$ & 0 & 0.32 & 0.47 & 0 & 1 \\
\hline Income level $(€ 1000)$ & $\begin{array}{c}1:<20 \\
\text { 2: between } 20 \text { mila and } 60 \\
3:>60\end{array}$ & 2 & 2 & 1 & 1 & 3 \\
\hline
\end{tabular}


of families had members over 18 years old. In terms of education, two major groups were observed: one with a high school diploma (about 38\%) and one with a bachelor's degree $(50.2 \%)$. The average educational level was about 4.22. The absolute majorities $(66.6 \%)$ were mainly employees $(38.5 \%)$, and total annual household revenue was distributed as follows: $25.5 \%$ (under $€ 20,000), 59.7 \%$ (€20,000 - €60,000), and 14.8\% (over $€ 60,000)$. Most respondents $(89 \%)$ were not members of an environmental association, while around $32 \%$ were owners of an olive farm with an average size of 0.75 ha. The overall descriptive analysis revealed a wide range of variables related to Sections 1 (opinion and awareness of the olive landscape in Apulia) and 3 (socio-economic profile) of the questionnaire.

\section{Estimates of willingness to pay}

Conditional logit models are estimated in order to disentangle potential heterogeneity in individual preferences. The results (Table 5, column 1) show that, as expected, additional costs required for landscape restoration are negatively correlated with respondent choices. With respect to changes in landscape, the correspondent coefficient estimate is positive, suggesting that local residents do not appreciate the "status quo" and tend to prefer other alternatives for landscape restoration. The average respondent is willing to pay $€ 3.52$ more for changes in landscape (for instance, to move from the status quo to a revived landscape). Considering the Apulian households $(1,618,809$ households), the average value that Apulians are willing to pay for landscape restora-

Table 5. Conditional Logit Models.

\begin{tabular}{|c|c|c|c|}
\hline Variables & Baseline (1) & Location (2) & Type of landscape (3) \\
\hline Cost & $\begin{array}{c}-0.008^{* * *} \\
(0.001)\end{array}$ & $\begin{array}{c}-0.009^{* * *} \\
(0.001)\end{array}$ & $\begin{array}{c}-0.016^{* * *} \\
(0.001)\end{array}$ \\
\hline Landscape & $\begin{array}{c}0.029^{* * *} \\
(0.007)\end{array}$ & & \\
\hline Landscape (Foggia) & & $\begin{array}{c}0.049^{* * *} \\
(0.010)\end{array}$ & \\
\hline Landscape (Lecce) & & $\begin{array}{c}0.051^{* * *} \\
(0.010)\end{array}$ & \\
\hline Landscape ( $X f$-resistant olive cultivars only traditional) & & & $\begin{array}{c}-0.707^{* * *} \\
(0.038)\end{array}$ \\
\hline Landscape (Xf-resistant olive cultivars only intensive) & & & $\begin{array}{c}-2.010^{* * *} \\
(0.077)\end{array}$ \\
\hline Landscape (Xf-resistant olive cultivars only dispersed/sparse) & & & $\begin{array}{c}1.775^{* * *} \\
(0.171) \\
\end{array}$ \\
\hline Landscape (mixed productive crops) & & & $\begin{array}{c}0.496^{* * *} \\
(0.042)\end{array}$ \\
\hline Landscape (mixed productive crops with bushes) & & & $\begin{array}{c}0.173^{* * *} \\
(0.020) \\
\end{array}$ \\
\hline Respondents & 683 & 683 & 683 \\
\hline Observations & 8,196 & 8,196 & 8,196 \\
\hline Pseudo $\mathrm{R}^{2}$ & 0.023 & 0.028 & 0.208 \\
\hline
\end{tabular}

Notes: Standard errors are in brackets. P value: ${ }^{*}=\mathrm{P} \leq 0.05 ;{ }^{* *}=\mathrm{P} \leq 0.01 ;{ }^{* * *}=\mathrm{P} \leq 0.001$. All specifications control for 'research' and 'picture'. Bari is the baseline location in specification (2). Status quo is the baseline in specification (3). 


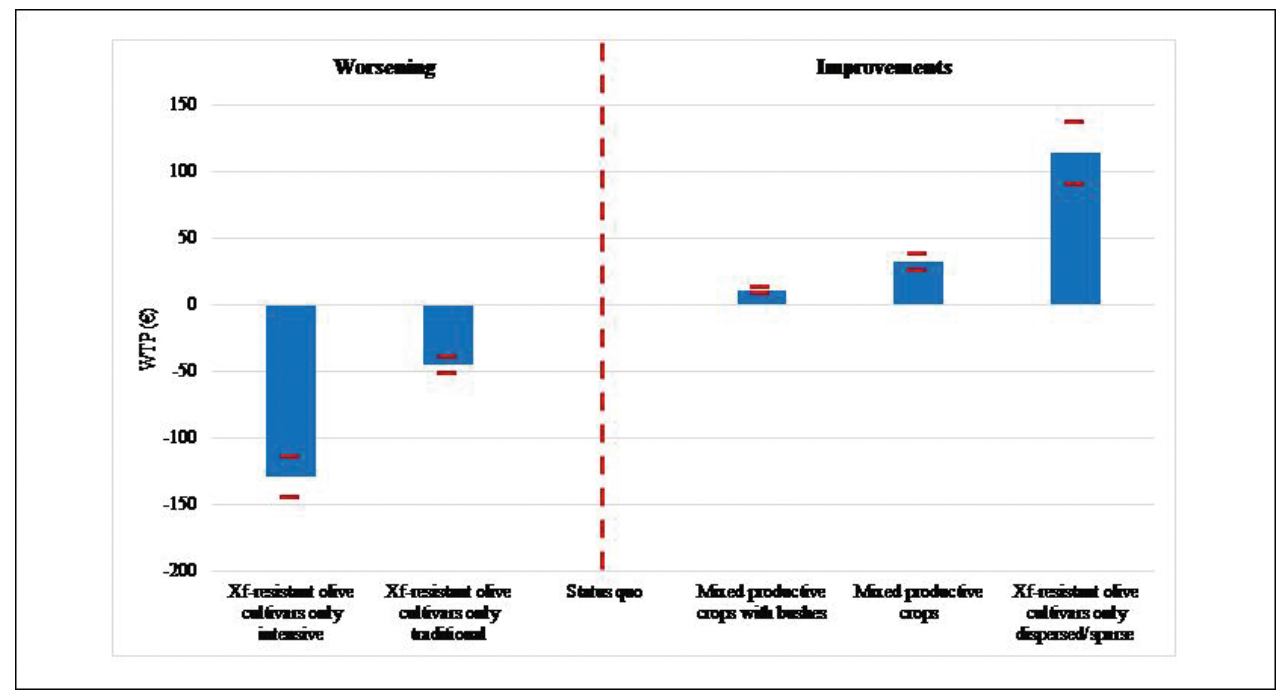

Figure 4. Willingness to pay (WTP) for replacing the status quo with different types of landscape. WTP (in $€$ ) are obtained from (statistically significant) coefficients estimated in the conditional logistic regressions (Table 5, column 3). Lower and upper levels are in red colour.

tion is about 5.7 million of $€$ per year. The preferences of respondents for changes in landscape tend to be homogeneous across locations (Table 5, column 2), but differ according to options for landscape restoration (Table 5, column 3). The estimated mean and $95 \%$ confidence intervals of WTP for options of landscape restoration are reported in Figure 4. Respondents are willing to pay $€ 113.92$ on average for $X f$-resistant olive cultivars, suggesting public preferences for a sparsely covered olive landscape for ecological reasons (lower consumption of soil, low use of chemical inputs, and mitigation of the greenhouse effect), and increasing this kind of extensive land mainly for its cultural and aesthetic values. In addition, mixed productive crops and mixed productive crops with alternating bushes alternatives, are also preferred by respondents: the average WTP is $€ 31.82$ and $€ 11.09$, respectively. This indicates that local people tend to enhance the diversity of the rural landscape and biodiversity conservation of the Apulia region. However, the reconversion to other crops will be possible in conditions of profitability and economic sustainability (El Chami et al. 2020). Differently, respondents tend to not prefer landscape characterized by Xf-resistant olive cultivars only with a traditional or an intensive system of production. This implies that they do not have strong views about the traditional dense olive groves and their economic effects (direct selling, niche market), social provisions (maintenance of family farming, rural employment), job opportunities for unemployed persons as well as on food security, in which olives and oil are common ingredients in Apulia region. Assuming that the total estimated damaged area is 53,800 ha (Italia Olivicola 2019), and that the total number of households in Apulia is 1,618,809 (Istituto Nazionale di Statistica 2019), the mean value of loss of the socio-ecological benefits is $1,059 € /$ ha. The total number of families 
was used instead of the total population, as stated by del Saz-Salazar and Menéndez (2007). However, the use of the total population will increase the mean value of loss to $€ 2,636$ per degenerated hectare.

\section{Discussion}

The findings explored in the Results provide a clear picture of respondents' opinions on the olive landscape, their preferences for the improvement of affected orchards, and their socio-economic profiles. Here we connect the observed results to the existing literature and derive some policy reflections from our findings. Firstly, our analysis highlights an extremely high level of perception of the cultural heritage and aesthetic benefits of the olive landscape. Previous research papers also assumed the importance of the assessment of cultural heritage values (Tengberg et al. 2012), as a subcategory of cultural ecosystem services (Hølleland et al. 2017) and aesthetic perception (Tribot et al. 2018) in landscape evaluation for sustainable land use planning and ecological restoration management. Rodríguez-Entrena et al. (2017) proposed the use of olive orchards to improve the aesthetic and visual quality of rural landscape's green cover. Secondly, our analysis shows that Apulia's inhabitants are willing on average to pay for alternative features in order to restore and revive the region's olive orchards. Obviously, the majority of respondents were found more likely to choose "landscape changes" over the current situation of degenerated land with diseased olive trees. Using plants and trees is hence preferred by citizens to mitigate the deterioration of rural landscape (Frontuto et al. 2020). Four types of alternative landscape features were proposed to the local public in the study area.

The highest WTP for landscape change was found for the landscape with $X f$-resistant olive cultivars in a dispersed or sparse production system, followed by mixed productive crops, and then by mixed productive crops with Mediterranean bushes. Given this, the present study underlines the relative public preferences to crop diversity in landscape configuration heterogeneity as outlined by Hass et al. (2018) and sustains existent evidence to biodiversity conservation and ecosystem features. However, the substitution of olive orchards with native plants or Mediterranean bushes alone certainly requires less maintenance throughout the year, provides a wildlife habitat (plant reproduction, bee abundance) and allows landscape conservation (Slattery et al. 2003).

Meanwhile, this type of landscape gives the lowest direct incomes for local farmers. These types of landscapes were selected over a monoculture cropping system planted with $X$-resistant olive cultivars in a traditional production system. On the other hand, the landscape with resistant- $X f$ olive cultivars in an intensive production system was relatively the least attractive option for land restoration. The lack of preferences for this kind of landscape seems to decrease local public utility. This perception is in agreement with a recent study (Arata et al. 2020), in which the mean WTP of Italian inhabitants in Lombardy region (northern Italy), is only $€ 6.7$ to increase the green area by $7 \%$. Local citizens attach a specific reconversion to other crops which were already in the 
past but appear to be gradually replaced by oil olive monoculture. These preferences diversify Apulia's agricultural landscape and enhance biodiversity in this region.

However, this kind of reconversion would be possible in conditions of profitability and economic sustainability over the new productions. Nevertheless, our findings support the results of Howley (2011), who found that intensive farming landscapes were less attractive for respondents. However, the dispersed production system provides fewer economic and social benefits than intensive production, as noted by Sardaro et al. (2016a). Furthermore, despite the fewer studies addressed to olive landscape valuation, the results of this research are relatively representative. A previous study by Marangon et al. (2008) assessed WTP for the introduction of olive trees into the landscape. The contingent valuation method applied on a hill region between Italy and Slovenia showed an average WTP of €25.59 household/year. Rodrígues-Entrena et al. (2017) stated that visitors' WTP per year is around €6.52 in terms of landscape restoration with parking fees to improve the aesthetic quality of the land. Torres-Miralles et al. (2017) estimated the WTP to sustain olive-growing with a natural reserve in Andalusia (Spain). Using CVM, the mean WTP was €37 household/year. Sardaro et al. (2016a) evaluated the benefits provided by olive landraces in Apulia, revealing that WTP for landscape preservation was $€ 207$ per year/family.

Furthermore, a number of studies elicited individual preferences in relation to environmental issues (such as landscape preferences) and multi-functionality of agriculture (Abler 2004; Dachary-Bernard and Rivaud 2013). Tempesta and Vecchiato (2017) have already reviewed previous Italian studies for evaluating landscape benefits. They found that WTP ranged from $€ 2.8$ to $€ 74.3$ per household/year. Ciaian and Paloma (2011) found that the mean WTP was €149 per ha, by using a metaanalysis technique of agriculture landscape valuation in EU. Our results highlight the relation between the mean WTP values and the distance from the degenerated landscape. Lecce residents live closer to the studied area and are relatively willing to pay more than Foggia residents (Figure 1). This proximity issue was analyzed by del Saz-Salazar and Menéndez (2007), who found a positive correlation between WTP and residence proximity. This issue was also stressed by Arata et al. (2020) as needing to be explored in future studies. The third contribution from the present study is the use of research as a conceptual contribution in designing choice experiment. Studies using this type of attribute are absent from the literature review for evaluation of ecosystem services.

\section{Conclusion}

Environmental issues such as restoration of damaged landscape are of crucial importance for land use development plans at regional, national and European levels (European Landscape Convention 2000). This convention urges each EU Member State "to assess the landscapes thus identified, taking into account the particular values assigned to them by the interested parties and the population concerned". In consequence, 
by assessing WTP and preferences of the local public towards alternative features or changes in landscape through the stated preferences approach, our study constitutes an efficient prerequisite tool to support local policy-makers on the allocation of financial resources in the best interest of the local inhabitants in the study area. This evidence was recently noted by Rewitzer et al. 2017; Arata et al. 2020 and Frontuto et al. 2020. Assessment of the social value of the damaged olive landscape in Puglia is based on landscape changes and pursuit of the ongoing research and experimentation on $X f$. The latter attribute is a specific challenge for the Italian landscape, given the economic impact of $X f$ subsp. pauca on olives. Reinforcement of the ongoing research on the production of transgenic olive plants and on vector control (i.e. tillage, weed management, use of insecticides, trapping, monitoring and surveillance) is necessary to reduce the economic impact of $X f$. Schneider et al. (2020) have highlighted the importance of the strengthening research to reduce the future spread rate of $X f$ from 5.18 to $1.1 \mathrm{~km} /$ year on Italian, Spanish and Greek olives. In fact, the production of resistant cultivars of olives is an important axis of research to cope with $X f$ invasion. In addition, through the replantation of potential damaged landscape by using resistant olive cultivars, the hypothetical economic impact of $X f$ on olives in these countries can also be reduced from a range of $€ 3.58$ to 8.69 billion (without replanting resistant olive cultivars) to a range of $€ 2$ to 4.13 billion (by replanting resistant cultivars), over a period of 50 years. Thus, the present study has important policy implications for the current regional recovery action plan (Mipaaft 2020) in the study area, particularly for the restoration and revival of damaged olive orchards, control of $X f$ vectors and enhancement of research and experimentation aimed at finding a cure for this disease. Lastly, the present choice experiment model could be enhanced by involving other landscape attributes related to the level or types of crops for reconversion, the safeguarding of ancient/monumental olive trees, and communication activities. This research could also be extended to cover the preferences of tourists and of local entrepreneurs for whom improvement of the olive groves would have positive impacts on income.

\section{Acknowledgements}

This research was supported by CURE-XF, an EU-funded project, coordinated by CIHEAM Bari (H2020 - MSCA - RISE. Reference number: 634353). Thanks also to Sarah Jane Christopher of UNIBA for her careful proof-reading of the manuscript and to the anonymous Referees for their valuable suggestions.

\section{References}

Abler D (2004) Multifunctionality, agricultural policy, and environmental policy. Agricultural and Resource Economics Review, Cambridge University Press 33(1): 8-17. https://doi. org/10.1017/S1068280500005591 
Arata L, Diluiso F, Guastella G, Pareglio S, Sckokai P (2020) Willingness to pay for alternative features of land-use policies: the case of the lake Garda region. Land Use Policy 100: e104942. https://doi.org/10.1016/j.landusepol.2020.104942

Arriaza-Balmón M, Gomez-Limon JA, Kallas Z, Nekhay O (2006) Andalusian demand for non-market goods from mountain olive groves. In 2006 Annual Meeting, August 12-18, 2006, Queensland, Australia 25385, International Association of Agricultural Economists. https://doi.org/10.22004/ag.econ.25385

Auffhammer M (2018) Quantifying economic damages from climate change. Journal of Economic Perspectives 32(4): 33-52. https://doi.org/10.1257/jep.32.4.33

Bateman IJ, Day BH, Jones AP, Jude S (2009) Reducing gain-loss asymmetry: a virtual reality choice experiment valuing land use change. Journal of Environmental Economics and Management 58: 106-118. https://doi.org/10.1016/j.jeem.2008.05.003

Beck PSA, Scholten R, Sanchez LM, Hornero A, Navas-Cortes JA, Pablo J, Zarco-Tejada PJ (2019) Monitoring the impact of Xylella fastidiosa on Apulia's olive orchards using sentinel-2 satellite data and aerial photographs. EFSA (European Food Safety Authority), Second European Conference on Xylella fastidiosa, October 29-30, 2019, Ajaccio, Corsica.

Bennett J, Blamey R (2001) The choice modelling approach to environmental valuation. Edward Elgar, Cheltenham, 288 pp. ISBN: 9781840643046.

Bernetti I, Franciosi C, Lombardi GV (2006) Land use change and the multifunctional role of agriculture: A spatial prediction model in an Italian rural area. International Journal of Agricultural Resources, Governance and Ecology 5(2-3): 145-161. https://doi.org/10.1504/ IJARGE.2006.009161

Bosco D (2014) Xylella fastidiosa: vettori accertati e potenziali in America e in Europa. Atti Accademia Nazionale Italiana di Entomologia, Anno LXII, Firenze, Tipografia Coppini, 187-191.

Bottero M, Cozza G, Fontana R, Monaco R (2017) Choice experiments: An Application for the corona verde landscape in Turin (Italy). In: Gervasi O et al. (Eds) Computational Science and Its Applications - ICCSA 2017. ICCSA 2017. Lecture Notes in Computer Science, vol 10406. Springer, Cham. https://doi.org/10.1007/978-3-319-62398-6_38

Brouwer R, Dekker T, John Rolfe J, Windle J (2010) Choice certainty and consistency in repeated choice experiments. Environmental and Resource Economics 46: 93-109. https:// doi.org/10.1007/s10640-009-9337-x

Burgess D, Graham F, David M, Myles P (2012) Landscape valuation: choice experiments or contingent valuation. $86^{\text {th }}$ Annual Conference, April 16-18, 2012, Warwick University, Coventry, UK 134984, Agricultural Economics Society. https://doi.org/10.22004/ ag.econ. 134984

Bush SA (2013) Optimal designs for stated choice experiments generated from fractional designs. Journal of Statistical Theory and Practice 8(2). https://doi.org/10.1080/15598608. 2013.805451

Campbell D (2007) Willingness to pay for rural landscape improvements: combining mixed logit and random-effects models. Journal of Agricultural Economics 58(3): 467-483. https://doi.org/10.1111/j.1477-9552.2007.00117.x

Campbell D, Hynes S (2011) Estimating the welfare impacts of agricultural landscape change in Ireland: a choice experiment approach. Journal of Environmental and Management 8: 1019-1039. https://doi.org/10.1080/09640568.2010.547691 
Caussade S, Ortúzar Jdd, Rizzi L, Hensher D (2005) Assessing the influence of design dimensions on stated choice estimates. Transportation Research Part B: Methodological 39: 621-640. https://doi.org/10.1016/j.trb.2004.07.006

Cherchi E, Hensher DA (2015) Workshop synthesis: stated preference surveys and experimental design, an audit of the journey so far and future research perspectives. Transportation Research Procedia 11: 154-164. https://doi.org/10.1016/j.trpro.2015.12.013

Christie M, Hanley N, Warren J, Hyde T, Murphy K, Wright R (2004) A valuation of biodiversity in the UK using choice experiments and contingent valuation. Applied Environmental Economics Conference, March 26, 2004. Royal Society.

Ciaian P, Gomez y Paloma S (2011) The value of EU agricultural landscape. Joint Research Centre, Working Papers JRC65456, Joint Research Centre (Seville site). https://ideas.repec.org/p/ipt/iptwpa/jrc65456.html

Ciervo M (2016) The olive quick decline syndrome (OQDS) diffusion in Apulia Region: An apparent contradiction according to the agricultural model. Belgian Geography Journal, 2016. https://doi.org/10.4000/belgeo.20290

Cornara D, Saponari M, Zeilinger AR, de Stradis A, Boscia D, Loconsole G, Bosco D, Martelli GP, Almeida RPP, Porcelli F (2017) Spittlebugs as vectors of Xylella fastidiosa in olive orchards in Italy. Journal of Pest Science 90: 521-530. https://doi.org/10.1007/s10340-016-0793-0

Corrado G, Imperato A, Mura M, Perri E, Rao R (2011) Genetic diversity among olive varieties of southern Italy and the traceability of olive oil using SSR markers. Journal of Horticulture Science and Biotechnology 86(5): 461-466. https://doi.org/10.1080/14620316.201 1.11512789

Cortignani R, Gobattoni F, Pelorosso R, Ripa MN (2018) Green Payment and Perceived Rural Landscape Quality: A Cost-Benefit Analysis in Central Italy. Sustainability 10(8): e2910. https://doi.org/10.3390/su10082910

Dachary-Bernard J, Rivaud A (2013) Assessing tourists' preferences for coastal land use management: oyster farming and heritage. Ocean and Coastal Management 84: 86-96. https:// doi.org/10.1016/j.ocecoaman.2013.07.011

Dallimer M, Jacobsen JB, Lundhede TH, Takkis K, Thorsen BoJ, Giergicnz M (2015) Patriotic values for public goods: transnational trade-offs for biodiversity and ecosystem services? Bioscience 65(1): 33-42. ISSN 0006-3568. https://doi.org/10.1093/biosci/biu187

De Ayala B, Ramos AH, Chladkova DM (2012) Landscape valuation through discrete choice experiments: Current practice and future research reflections. Biltoki; 2012-03, Universidad del País Vasco - Departamento de Economía Aplicada III (Econometría y Estadística). de Groot RS, Wilson MA, Boumans, RMJ (2002) A Typology for the classification, description and valuation of ecosystem functions, goods and services. Ecological Economics 41: 393-408. https://doi.org/10.1016/S0921-8009(02)00089-7

del Saz-Salazar S, Menéndez LG (2007) Estimating the non-market benefits of an urban park: Does proximity matter? Land Use Policy 24(1): 296-305. https://doi.org/10.1016/j.landusepol.2005.05.011

European Food Safety Authority Panel on Plant Health (2015) Scientific Opinion on the risks to plant health posed by Xylella fastidiosa in the EU territory, with the identification and evaluation of risk reduction options. EFSA Journal 2015 13(1): e3989. [262 pp.] https:// doi.org/10.2903/j.efsa.2015.3989 
Elbeaino T, Yaseen T, Valentini F, Ben Moussa IE, Mazzoni V D’Onghia AM (2014) Identification of three potential insect vectors of Xylella fastidiosa in southern Italy. Phytopathologia Mediterranea 53: 328-332. https://doi.org/10.14601/Phytopathol_Mediterr-14113

El Chami D, Daccache A, El Moujabber M (2020) How can sustainable agriculture increase climate resilience? A systematic review. Sustainability 12(8): e3119. https://doi.org/10.3390/ su12083119

Emerton L, Howard G (2008) A toolkit for the economic analysis of invasive species. Global Invasive Species Programme, Nairobi, Kenya. https://doi.org/10.13140/2.1.5009.0562

European Landscape Convention (2000) European Landscape Convention. https://www.coe. int/en/web/landscape/

Fernández-Habas J, Sánchez-Zamora P, Gallardo-Cobos R, Ceña-Delgado F (2018) (2) Assessment of ecosystem services provision: The case of mountain olive groves in Los Pedroches, southern Spain. New Medit, 17. https://doi.org/10.30682/nm1802d

Frem M, Chapman D, Fucilli V, Choueiri E, Moujabber ME, Notte PL, Nigro F (2020) Xylella fastidiosa invasion of new countries in Europe, the Middle East and North Africa: Ranking the potential exposure scenarios. NeoBiota 59: 77-97. https://doi.org/10.3897/ neobiota.59.53208

Frontuto V, Corsi A, Novelli S, Gullino P, Larcher F (2020) The visual impact of agricultural sheds on rural landscapes: the willingness to pay for mitigation solutions and treatment effects. Land Use Policy 91: e104337. https://doi.org/10.1016/j.landusepol.2019.104337

Garrod G, Ruto E, Powe N (2014) Investigating preferences for the local delivery of agrienvironment benefits. Journal of Agricultural Economics 65(1): 177-190. https://doi. org/10.1111/1477-9552.12040

Giampetruzzi A, Morelli M, Saponari M, Loconsole G, Chiumenti M, Boscia D, Savino V, Martelli GP Saldarelli P (2016) Transcriptome profiling of two olive cultivars in response to infection by the CoDiRO strain of Xylella fastidiosa subsp. pauca. BMC Genomics 17: e475. https://doi.org/10.1186/s12864-016-2833-9

Giampetruzzi A, Saponari M, Almeida RPP, Essakhi S, Boscia D, Loconsole G, Saldarelli P (2017) Complete genome sequence of the olive-infecting strain Xylella fastidiosa subsp. pauca De Donno. Genome Announcements 5: e00569-17. https://doi.org/10.1128/ genomeA.00569-17

Haltia E (2015) Contingent valuation and choice experiment of citizens' willingness to pay for forest conservation in southern Finland. Dissertationes Forestales 204: e85. https://doi. org/10.14214/df.204

Hanley N, Mourato S, Wright RE (2001) Choice modelling approaches: a superior alternative for environmental valuation? Journal of Economic Survey 15(3): 435-462. https://doi. org/10.1111/1467-6419.00145

Hass AL, Kormann UG, Tscharntke T, Clough Y, Baillod AB, Sirami C, Fahrig L, Martin JL, Baudry J, Bertrand C, Bosch J, Brotons L, Burel F, Georges R, Giralt D, Marcos-García MÁ, Ricarte A, Siriwardena G, Batáry P (2018) Landscape configurational heterogeneity by small-scale agriculture, not crop diversity, maintains pollinators and plant reproduction in Western Europe. Proceedings of the Royal Society B Biological Sciences 285(1872): e20172242. https://doi.org/10.1098/rspb.2017.2242 
Hasund KP, Kataria M, Lagerkvist CJ (2011) Valuing public goods of the agricultural landscape: a choice experiment using reference points to capture observable heterogeneity. Journal of Environmental Planning and Management 54(1): 31-53. https://doi.org/10.1080/ 09640568.2010 .502753

Hølleland H, Skrede J, Sanne Bech Holmgaard SB (2017) Cultural heritage and ecosystem services: a literature review. Conservation and Management of Archaeological Sites 19(3): 210-237. https://doi.org/10.1080/13505033.2017.1342069

Howley P (2011) Landscape aesthetics: assessing the general publics' preferences towards rural landscapes. Ecological Economics 72: 161-169. https://doi.org/10.1016/j. ecolecon.2011.09.026

Hoyos D (2010) The state of the art of environmental valuation with discrete choice experiments. Ecological Economics 69(8): 1595-1603. https://doi.org/10.1016/j. ecolecon.2010.04.011

Istituto Nazionale di Statistica (2019) Istituto Nazionale di Statistica. https://www.istat.it/. Extraction date: 19/04/2020

Italia Olivicola - Consorzio Nazionale (2019) Proposta per un piano straordinario di riconversione e di ristrutturazione degli oliveti salentini. Report, 6 pp. https://www.italiaolivicola. it/wp-content/uploads/2019/02/Studio-piano-xylella.pdf

Johansson PO (1990) Valuing environmental damage. Oxford Review of Economic Policy 6(1): 34-50. https://doi.org/10.1093/oxrep/6.1.34

Kallas Z, Gómez-Limón JA, Arriaza M (2007) Are citizens willing to pay for agricultural multifunctionality? Agricultural Economics 36: 405-419. https://doi.org/10.1111/j.15740862.2007.00216.x

Lanfranchi M, Giannetto C (2012) Olive-Growing in Italy: economic and multifunctional aspects. International Journal of Academic Research in Accounting, Finance and Management Sciences 2(1): 282-292. ISSN: 2225-8329.

Marangon F, Troiano S, Visintin F (2008) The economic value of olive plantation in rural areas. A study on a hill region between Italy and Slovenia. European Association of Agricultural Economists, 2008 International Congress, August 26-29, 2008, Ghent, Belgium. https:// doi.org/10.22004/ag.econ.44412

Martelli G, Boscia D, Porcelli F, Saponari M (2015) The olive quick decline syndrome in southeast Italy: a threatening phytosanitary emergency. European Journal of Plant Pathology: e144. https://doi.org/10.1007/s10658-015-0784-7

Ministero delle politiche agricole alimentari, forestali e del turismo (2020) Ministero delle politiche agricole alimentari, forestali e del turismo. https:/www.politicheagricole.it/flex/ $\mathrm{cm} /$ pages/ServeBLOB.php/L/IT/IDPagina/15174

Novikova A, Rocchi L, Vaznonis B (2019) Valuing agricultural landscape: Lithuanian case study using a contingent valuation method. Sustainability 11: e2648. https://doi.org/10.3390/ su11092648

Plan Bleu (2016) Assessment of the socio-economic value of the goods and services provided by Mediterranean forest ecosystems. Food and Agriculture Organization of the United Nations and Plan Bleu pour l'Environnement et le Développement en Méditerranée. Technical report, $45 \mathrm{pp}$. 
Portney PR (1994) The contingent valuation debate: why economists should care. Journal of Economic perspectives 8(4): 3-17. https://doi.org/10.1257/jep.8.4.3

Rewitzer S, Huber R, Grêt-Regamey A, Barkmann J (2017) Economic valuation of cultural ecosystem service changes to a landscape in the Swiss Alps. Ecosystem Services, Elsevier, vol. 26(PA): 197-208. https://doi.org/10.1016/j.ecoser.2017.06.014

Rodríguez-Entrena M, Colombo S, Arriaza M (2017) The landscape of olive groves as a driver of the rural economy. Land Use Policy 65: 164-175. https://doi.org/10.1016/j.landusepol.2017.03.017

Saponari M, Boscia D, Loconsole G, Palmisano F, Savino V, Potere O (2014) New hosts of Xylella fastidiosa strain CoDIRO in Apulia. Journal of Plant Pathology 96: e611. http:// doi.org/10.4454/JPP.V96I3.008

Saponari M, Boscia D, Nigro F, Martelli GP (2013) Identification of DNA sequences related to Xylella fastidiosa in oleander, almond and olive trees exhibiting leaf scorch symptoms in Apulia (southern Italy). Journal of Plant Pathology 95: e668. http://doi.org/10.4454/JPP. V95I3.035

Saponari M, Giampetruzzi A, Loconsole G, Boscia D, Saldarelli P (2018) Xylella fastidiosa in Olive in Apulia: Where we stand. Phytopathology: e109. https://doi.org/10.1094/PHYTO-08-18-0319-FI

Saponari M (2016) State of the art of the research on Xylella fastidiosa in Apulia. FAO-IPPCCIHEAM International Workshop on Xylella fastidiosa and the Olive Quick Decline Syndrome (OQDS), Valenzano (Bari), Italy.

Sardaro R, Acciani C, De Gennaro BC, Fucilli V, Roselli L (2015) Economic and landscape impact assessment of the disease caused by Xylella fastidiosa to olive growing in the Salento area (southern Italy). In: Castellini A, Devenuto L (Eds) Il Danno Elementi Giuridici, Urbanistici e Economico-Estimativi. Universitas Studiorum, Mantova, 345-372.

Sardaro R, Fucilli V, Acciani C, Bozzo F, Petrontino A, Girone S (2016a) Agro-biodiversity: an economic evaluation of benefits provided to regional community by the Apulian olive landraces. Rivista Italiana di Economia Demografia e Statistica Volume LXX n.3 LuglioSettembre, $12 \mathrm{pp}$.

Sardaro R, Girone S, Acciani C, Bozzo F, Petrontino A, Fucilli V (2016b) Agro-biodiversity of Mediterranean crops: farmers' preferences in support of a conservation programme for olive landraces. Biological Conservation 201: 210-219. https://doi.org/10.1016/j.biocon.2016.06.033

Scarpa R, Cicia G (2000) Willingness to Pay for rural landscape preservation: A case study in Mediterranean agriculture (July 2000). FEEM Working Paper No. 59.2000. https://doi. org/10.2139/ssrn.237570

Scarpa R, Campbell D, Hutchinson Wl (2007) Benefit estimates for landscape improvements: sequential bayesian design and respondents' rationality in a choice experiment. Land Economics 83(4): 617-634. https://doi.org/10.3368/le.83.4.617

Schneider K, van der Werf W, Cendoya M, Mourits M, Navas-Cortés JA, Vicent A, Oude Lansink A (2020) Impact of Xylella fastidiosa subspecies pauca in European olives. Proceedings of the National Academy of Sciences 117(17): 9250-9259. https://doi.org/10.1073/ pnas. 1912206117 
Severini S (2006) La nuova OCM olio d'oliva: come risponderanno gli olivicoltori?, Agriregionieuropa, n. 4. http://agriregionieuropa.univpm.it/

Slattery BE, Reshetiloff K, Zwicker SM (2003) Native Plants for Wildlife Habitat and Conservation Landscaping: Chesapeake Bay Watershed. U.S. Fish \& Wildlife Service, Chesapeake Bay Field Office, Annapolis, MD, 82 pp.

Tagliafierro C, Longo A, Van Eetvelde V, Antrop M, Hutchinson WG (2013) Landscape economic valuation by integrating landscape ecology into landscape economics. Environmental Science \& Policy. https://doi.org/10.1016/j.envsci.2012.12.001

Tempesta T, Vecchiato D (2017) Valuing the landscape benefits of rural policies actions in Veneto (Italy). Aestimum, 70, 7-30. http://dx.doi.org/10.13128/Aestimum-21079

Tempesta T (2014) People's preferences and landscape evaluation in Italy: A review. New Medit 13(1): 50-59.

Tengberg A, Fredholm S, Eliasson I, Knez I, Saltzman K, Wetterberg O (2012). Cultural ecosystem services provided by landscapes: assessment of heritage values and identity Ecosystem Services 2: 14-26. https://doi.org/10.1016/j.ecoser.2012.07.006

Torgler B, Garcia-Valiňas M (2007) The determinants of individuals' attitudes towards preventing environmental damage. Ecological Economics 63(2-3): 536-552. https://doi. org/10.1016/j.ecolecon.2006.12.013

Torres-Miralles M, Grammatikopoulou I, Rescia AJ (2017) Employing contingent and inferred valuation methods to evaluate the conservation of olive groves and associated ecosystem services in Andalusia (Spain). Ecosystem Services 26: 258-269. https://doi.org/10.1016/j. ecoser.2017.07.002

Torquati B, Boggia A, Massei G, Bartolini S (2006) L'olivicoltura nelle zone marginali tra disaccoppiamento, condizionalità, tutela paesaggistica ed idrogeologica, Economia e Diritto Agroalimentare 3: 43-62.

Tribot AS, Deter J, Mouquet N (2018) Integrating the aesthetic value and landscapes and biological diversity. Proceedings of the Royal Society B: Biological Sciences 285: e20180971. https://doi.org/10.1098/rspb.2018.0971

Viganò L (2006) Il sostegno comunitario all'olio d'oliva: prospettive di intervento nel quadro delle politiche di sviluppo rurale, in: Il sostegno comunitario all'olio d'oliva: implicazioni della riforma dell'OCM per l'Italia e prospettive di intervento nel quadro delle politiche di sviluppo rurale, Proceedings conference, 20 June 2006, Roma.

Weller P, Oehlmann M, Mariel P, Meyerhoff J (2014) Stated and inferred attribute non-attendance in a design of designs approach. Journal of Choice Modelling 11: 43-56. https://doi. org/10.1016/j.jocm.2014.04.002

Wells JM, Raju BC, Hung HY, Weisburg WG, Mandelco-Paul L, Brenner DJ (1987) Xylella fastidiosa gen. nov., sp. nov.: Gram-negative, xylem-limited, fastidious plant bacteria related to Xanthomonas spp. International Journal of Systematic Bacteriology 37(2): 136-143. https://doi.org/10.1099/00207713-37-2-136

Zoderer BM, Lupo Stanghellini PS, Tasser E, Walde J, Wieser H, Tappeiner U (2015) Exploring socio-cultural values of ecosystem service categories in the Central Alps: the influence of socio-demographic factors and landscape type. Regional Environmental Change 16(7): 2033-2044. https://doi.org/10.1007/s10113-015-0922-y 


\section{Supplementary material I}

\section{The questionnaire ( 1 block of 3 is presented hereafter)}

Authors: Michel Frem, Fabio Gaetano Santeramo, Emilia Lamonaca, Maroun El Moujabber, Elia Choueiri, Pierfederico La Notte, Franco Nigro, Francesco Bozzo, Vincenzo Fucilli Data type: text

Copyright notice: This dataset is made available under the Open Database License (http://opendatacommons.org/licenses/odbl/1.0/). The Open Database License $(\mathrm{ODbL})$ is a license agreement intended to allow users to freely share, modify, and use this Dataset while maintaining this same freedom for others, provided that the original source and author(s) are credited.

Link: https://doi.org/10.3897/neobiota.66.67648.suppl1 